\title{
Orthodox Church in Tsar Russia
}

\section{Antoni Mironowicz}

\author{
Uniwersytet w Białymstoku
}

Polska

amir@uwb.edu.pl

\begin{abstract}
The liberation of the Muscovite lands from the Mongol oppression coincided with the fall of Constantinople. The inhabitants of Muscovy were convinced, in line with the Byzantine tradition, that the state was necessary for salvation just as the Orthodox Church, while the close ties between the state and the Church symbolised God's covenant with people. After 1453, the Orthodox society of Muscovy were commonly of the opinion that the legitimacy of the Byzantine Empire vested into the new „Third Rome”, i.e. Moscow. That idea began assuming a more tangible shape during the reign of Ivan IV the Terrible. The ruler was officially crowned as Tsar and the abbot of the Volokolamsky monastery Josef declared that the Orthodox Church and the state should unite in making the Kingdom of God come true in the earth. Russian Orthodoxy was torn by a disagreement over the issue of monastic life and attitude to the earthly power. Nil Sorsky (1433-1508) and the Hesychasts from the forest hermitages beyond the Volga river claimed that the Orthodox Church should be independent of the state and it should not resort to state administration in religious matters. According to Nil Sorsky, monasteries should remain poor and denounce the ownership of land.
\end{abstract}

That time witnessed a dynamic development of the monastic centre on the Solovetsky Islands in the White Sea. Solovetsky saints Savvatii, Zosima and Herman launched a magnificent spiritual centre of Russian Orthodoxy. During the reign of Ivan IV the conflict was unavoidable also between the ruler and the clergy. The Metropolitan of Moscow Philip demanded that the Orthodox Church gain autonomy - and fell victim to Tsar's fury. After Ivan IV's death, during the rule of Boris Godunov, in 1589 Moscow was granted the status of a patriarchate. Metropolitan of Moscow, Job was appointed the first patriarch of Moscow and All Russia.

Muscovy was first named Russia in the late 15th century. The name was popularised during the 16th century and in 1721 it became the official designation of the state. Until 1694 the relations between the state and the Church were exemplarily harmonious. Religious life in Russia was overthrown during the reign of Peter I (1682-1725). The Russian Orthodox Church could not form an effective opposition to the political reforms of Peter I who, after the death of patriarch Adrian (1700), obstructed the election of his successor. Finally, Peter the Great abolished the patriarchate and replaced it with the institution of the Holy Synod, whose members were appointed by himself. The 18th century witnessed another revival of religious life in Russia, accompanied by the growing importance of the Orthodox Church in the public sphere. The Russian theological school was stimulated by the more and more popular teachings of bishop of Voronezh St. Tikhon Zadonsky. Inspired by the Gospel and the works of the Holy Fathers of Orthodoxy, his preaching promoted the idea of the common character of human salvation. Owing to his efforts new monastic centres, specialised in contemplation and prayer, were founded in the 19th century. The Russian monasticism was increasingly moved by the institution of Elderhood (starchestvo), the body of monks of eminent piety and wisdom. The revival of monastic life was instigated by the monk St. Paisius Velichkovsky, who lived in the 18th century. The views of the charismatic elderly who had the gift of prophecy (monks of the Optina hermitage), and especially those of St. Seraphim of Sarov, influenced the Russian elites, including Tsar himself. In the 19th century the Russian Empire Tsar promoted the ideology of an Orthodox state based on a symbiosis of „Orthodoxy, absolutism and nationality”. The circles of the higher clergy recultivated the ideas of the Church's independence of the state. Metropolitan of Moscow Filaret was an ardent supporter of the Church's autonomy. Other bishops, faced with the failure of any efforts to free the Orthodox Church from dependence on the state, chose to live monastic life, as for instance St. Ignatius Branchaninov, St. Ambrosius of the Optina hermitage or Theophan the Hermit. Another movement among the clergy was represented by St. Ioann of Kronstadt (1829-1909). The priest hailed the participation in everyday liturgy, support to the poor and the need for educating social masses.

In the early 20th century the Orthodox Church raised the demands of independence and reactivation of patriarchate. The outbreak of World War I and the defeats suffered in the first years of the war made the revolutionary tendencies imminent. In the times of both revolutions, in 1917, the Orthodox Church remained faithful to Tsar. After the subversion of monarchy but before the Bolshevik prosecutions of the Orthodox Church began, the Kremlin Synod managed to restore the canonical elect ability of bishops and reactivate the patriarchate. Archbishop of Vilnius Tikhon was appointed patriarch of Moscow in 1918.

Streszczenie: W tworzeniu duchowych wartości narodu rosyjskiego, szczególna rola przypadła świętym z nim związanych. Pierwszymi kanonizowanymi świętymi byli kniaziowie Borys i Gleb, nazwani na chrzcie imionami Roman i Dawid. Borys i Gleb zostali uznani za świętych jako „strastotierpcy”, tzn. cierpiący męki. W ten sposób powstał nowy typ świętości, znany szczególnie na ziemiach ruskich. Tytuł ,równy apostołom” w tradycji bizantyjskiej przypisuje się zwykle pierwszym misjonarzom danego kraju. W przypadku ziem ruskich mianem tym określano księżnę Olgę i księcia Włodzimierza. Kolejną grupą wśród pierwszych świętych ruskich są „podwiżniki”. Określenie to dotyczy osób duchownych i świeckich podejmujących heroiczny wysiłek duchowo-ascetyczny (Antoni i Teodozy Pieczerski, Cyryl Turowski). Osobna grupę świętych w Rosji stanowią „błagowierni” książęta. Mianem tym określano panujących, którzy przyczynili się do rozwoju chrześcijaństwa i prowadzili życie zgodne z nauką Cerkwi. Do tego grona należy książę smoleński Rościsław i księcia Aleksandra Newskiego.

Odrodzenia życia religijnego na Rusi Moskiewskiej nastąpiło w XIV w. Na dużą skalę rozwijało się życie monastyczne, a chrześcijaństwo przeniknęło do wszystkich form życia (polityki, kultury, etc.). Nowy impuls do życia duchowego mieszkańców ziem ruskich wniósł św. Sergiusz z Radoneża, propagator życia kontemplacyjnego i założyciel Ławry Św. Trójcy. Wyzwolenie ziem ruskich z niewoli mongolskiej zbiegło się w czasie z upadkiem Konstantynopola. Mieszkańcy Księstwa Moskiewskiego uważali, zgodnie z tradycją bizantyjską, że państwo jest tak samo potrzebne do zbawienia jak Cerkiew, a ścisłe powiązanie państwa z Cerkwią wyraża związek ludzi z Bogiem. Po 1453 r., na Rusi Moskiewskiej, wśród prawosławnych powszechnie panowało przekonanie, że uprawnienia cesarstwa bizantyjskiego przeszły na „Trzeci Rzym”, czyli Moskwę. W tym okresie nastąpił rozwój ośrodka zakonnego na Wyspach Sołowieckich na Morzu Białym. Święci mnisi sołowieccy Sawwati, Zosima i Herman stworzyli wielkie duchowe centrum 
rosyjskiego prawosławia. Za panowania Iwana IV doszło do konfliktu między panującym a duchowieństwem. Metropolita moskiewski Filip domagał się niezależności Cerkwi i padł ofiarą gniewu carskiego. Po śmierci Iwana IV, za panowania Borysa Godunowa ustanowiono w 1589 r. w Moskwie patriarchat. Pierwszym patriarchą został metropolita moskiewski Hiob.

Lata „,wielkiej smuty” ponownie zjednoczyły Cerkiew i państwo. Do 1694 r. w stosunkach między państwem a Kościołem panowała pełnia harmonia. Istotne zmiany w życiu religijnym Rosji nastąpiły za panowania Piotra I. Rosyjska Cerkiew Prawosławna nie potrafiła skutecznie przeciwstawić się reformom politycznym Piotra I, który po śmierci patriarchy Adriana (1700) nie dopuścił do wyboru jego następcy. Ostatecznie Piotr Wielki zniósł patriarchat i zastąpił go instytucją Świątobliwego Synodu. W XVIII w. doszło do ponownego odrodzenia życia religijnego w Rosji i wzrostu znaczenia Cerkwi prawosławnej w życiu publicznym. Rozwój myśli teologicznej nastąpił w Rosji za sprawą upowszechnienia się nauczania św. Tichona Zadońskiego. Odnowę życia zakonnego zapoczątkował żyjący w XVIII w. mnich Paisij Wieliczkowski. Poglądy charyzmatycznych starców, obdarzonych szczególnymi zdolnościami przewidywania (mnisi z pustelni Optino, św. Serafim Sarowski) wpływały na elity społeczeństwa ruskiego z carem włącznie. W XIX wieku carat w celu zapewnienia sobie poparcia ludności rosyjskiej popierał ideologię państwa prawosławnego opartego na symbiozie „prawosławia, samowładztwa i narodowości”. W środowisku wyższego duchowieństwa odradzały się tendencje niezależności Cerkwi od państwa. Zwolennikiem autonomii Cerkwi był metropolita moskiewski Filaret. Biskupi, nie mogąc uniezależnić Cerkwi od wpływu państwa, wybierali życie w klasztorze np. Ignatij Brianczaninow, Ambroży z pustelni Optino czy Teofan Pustelnik. Inny nurt w postawie duchowieństwa reprezentował św. Iwan z Kronsztadu. Kapłan propagował udział w codziennej liturgii, pomoc biednym i głosił potrzebę niesienia oświaty szerokim masom.

Na początku XX w. Cerkiew domagała się przywrócenia niezależności od państwa i reaktywowania patriarchatu. W okresie I wojny światowej i dwóch rewolucji 1917 r. Cerkiew pozostała wierna carowi. Po obaleniu monarchii, zanim rozpoczęły się prześladowania Cerkwi przez bolszewików, doszło na Kremlu do zwołania soboru, na którym przywrócono kanoniczną wybieralność biskupów i reaktywowano patriarchat. Patriarchą moskiewskim został w 1918 r. arcybiskup wileński Tichon.

Keywords: Orthodox Church, tsar, Russia

Slowa kluczowe: cerkiew prawosławna, carat, Rosja

The Russian Orthodox Church was and is the most numerous faith community in the Russian Federation, Belarus, Moldavia and Ukraine. ${ }^{1}$ Eastern Christianity has been a fixed component of religious life over a thousand years of the Russian history. At the end of the $15^{\text {th }}$ century Russia assumed the patronage over Orthodox Christianity and its rulers proclaimed themselves the heirs of the Byzantine statehood and cultural tradition. The recognition of the constant presence of this great Christian tradition is essential to the understanding of religious and national identity of the Russians and other local societies.

The first wave of Christianisation in the Ruthenian lands came with Byzantine missionaries in ca. 866 A.D. Most likely it was also the foundation date of the first Orthodox church named by St. Elias and the missionary metropolis in Kiev. ${ }^{2}$ The Greek Orthodox Church gained the opportunity to lead missions among the Eastern Slavs. Emperor Constantine VII Porphyrogenites (913-959 A.D.) endeavoured to draw the vast Ruthenian territories under the Byzantine power. The emperor took advantage of Kiev Princess Olga's, the widow of Prince Igor, stay in Constantinople (955 A.D.) to make her accept baptism on the Bos-

For the role of the Orthodox Church in the history of Russia cf. L. Bazylow, Historia Rosji, vol. I-II, Warszawa 1983; L. Kucharzewski, Od biatego caratu do czerwonego, vol. I-II, Warszawa 1990; J. Ochmański, Dzieje Rosji do roku 1861, Warszawa 1986; R. Pipes, Rosja carów, Warszawa 1990; J. C. Roberti, N. Struvé, D. Popielovski, Historie de l'Église russe, Nouvelle Cité, Paris 1989; W. A. Serczyk, Poczet władców Rosji, Londyn 1992; Z. Wójcik, Dzieje Rosji 1533-1801, Warszawa 1981.

2 Powieść minionych lat. Charakterystyka historyczno-literacka, translated and commented by F. Sielicki, Wrocław 1968, p. 248; O. M. Rapov, Russkaja Tserkov'w IX-piervoj trieti XII v., Moscow 1988, pp. $77-90$. porus. ${ }^{3}$ During the sacrament Princess Olga assumed the Christian name of Helena, after the Byzantine empress. ${ }^{4}$ During her reign the first Christian churches were founded in the city of Kiev. After Olga's death, pagan tendencies regained prevalence in Ruthenia. The ultimate Christianisation of Kiev Ruthenia took place during the rule of Vladimir the Great (980-1015 A.D.). ${ }^{5}$

The adoption of Christianity by Kiev Ruthenia from Byzantium in 988 determined the history and culture of the Russians, Belarusians and Ukrainians for the subsequent several centuries. Mediated by the Orthodox Church, the Byzantine culture took only two hundred years to spread all over Ruthenia, just as it had done before in Bulgaria and Serbia. Thus, in the late $10^{\text {th }}$ century the vastest Slavic state of the then Europe was officially bound with the Byzantine civilisation and its cultural legacy. The structures of the Orthodox Church developed dynamically. Besides the Kievan see, two other metropolises were established in Belgorod and Novgorod until the end of the $10^{\text {th }}$ century. In the early $11^{\text {th }}$ century, diocese cathedrals were founded in Polotsk, Chernihiv and Pereyaslav. From the second half of the $11^{\text {th }}$ and through the $12^{\text {th }}$ century new Episcopal seats were es-

\footnotetext{
Kroniki staroruskie, F. Sielicki, ed., Warszawa 1987, pp. 43-45.

4 A. Poppe, Olga, [In:] Stownik Starożytności Stowiańskich, vol. III, Wrocław 1975, pp. 477-478; I. Ševčenko, Byzantine Roots of Ukrainian Christianity, Harvard University 1984; S. Senyk, A History of the Church in Ukraine, vol. I, Roma 1993.

5 A detailed reconstruction of Ruthenia's baptism has been recently made by: A. Poppe, Ruś i Bizancjum w latach 986-989, Kwartalnik Historyczny, R. LI, issue 1, 1978, pp. 3-22; idem, The Rise of Christian Russia, London 1982; G. Podskalsky, Christentum und theologische Literatur in der Kiever Rus '(988-1237), München 1982; M. Brajcheśkyj, Utverdzhennia Khrystyjanstva na Rusy, Kiev 1988; O. M. Rapov, Russkaja Tserkov' w IX-piervoj trieti XII v., Moscow 1988; S. Senyk, A History of the Church in Ukraine, vol. I, Roma 1993; J. Swastek, Chrzest Rusi, pp. 55-71.
} 
tablished in Juriev, Rostov, Tmutarakan, Vladimir-Volynski, Turov, Smolensk and Halich. In the mid-13 ${ }^{\text {th }}$ century the Ruthenian lands were divided into 15 dioceses, which in terms of territorial size equalled some countries of Western Europe. ${ }^{6}$ At that time, Ruthenia's adherence to Christianity ensured the country an important position in Europe. In the centuries that followed it was Ruthenia that replaced Byzantium in defending the Eastern Christian tradition against the threats posed by Asian and Turkic peoples.

The liberation of the Muscovite lands from the Mongol oppression coincided with the fall of Constantinople. The inhabitants of Muscovy were convinced, in line with the Byzantine tradition, that the state was necessary for salvation just as the Orthodox Church, while the close ties between the state and the Church symbolised God's covenant with people. After 1453, the Orthodox society of Muscovy were commonly of the opinion that the legitimacy of the Byzantine Empire vested into the new „Third Rome”, i.e. Moscow. The process of sacralisation of princely power began from the time of Ivan III's marriage with Sophia, the nephew of the last member of the Byzantine Paleologist Dynasty. The conviction that the Russian Orthodox Church was the protector of true Christianity while Moscow was the capital of the new Empire was clearly expressed in The Epistle to Great Prince Vasilii to Enforce the Proper Application of the Sign of the Cross by His Subjects and Suppress Homosexuality, authored by monk Philoteus of the Pskov monastery and addressed to Great Prince Vasilii III (1505-1533). It was then that the monk of Pskov referred to Moscow for the first time as the „Third Rome". That idea began assuming a more tangible shape during the reign of Ivan IV the Terrible. The ruler was officially crowned as Tsar and the abbot of the Volokolamsky monastery Josef (1439-1515) declared that the Orthodox Church and the state should unite in making the Kingdom of God come true in the earth. Per St. Josef Volokolamsky, an earthly ruler had his nature furnished with divine prerogatives due to his providential role. The then cooperation between the state and the Orthodox Church had been a long-established fact. However, it did not mean that the Russian Orthodox Church was free from internal dissent.

Russian Orthodoxy was torn by a disagreement over the issue of monastic life and attitude to the earthly power. Nil Sorsky (1433-1508) and the Hesychasts from the forest hermitages beyond the Volga river claimed that the Orthodox Church should be independent of the state and it should not resort to state administration in religious matters. According to Nil Sorsky, monasteries should remain poor and denounce the ownership of land.

On the other hand, Josef Volokolamsky hailed the close relationship between the Orthodox Church and the state. The monk of Volokolamsk argued that monasteries were entitled to the ownership of land and should cooperate with lay rulers, as it was the only way for them to pursue

\footnotetext{
6 A. Poppe, Państwo i Kościól na Rusi w XI w., Warszawa 1968.

A. W. Serczyk, Prehistoria imperium czyli imperialne oblicze absolutyzmu rosyjskiego, [In:] Cywilizacja Rosji Imperialnej, P. Kraszewski, ed., Poznań 2002, pp. 31-33.
}

their social mission. ${ }^{8}$ Under the influence of his teachings, when Muscovy was plagued in the late $15^{\text {th }}$ century by numerous sects of the Barbers (Strigolnikiy) and the Judaisers (Zhidovstvuyushchiye), both the ruler and the Orthodox hierarchy undertook joint efforts to suppress them. ${ }^{9}$

The development of spiritual life was essentially marked by Maxim the Greek of Epirus (1480-1556), brought to Muscovy with the task of translating liturgical texts. Maxim the Greek supported the arguments of Nil Sorsky's disciples, which deserved him imprisonment by Ivan IV. Ultimately, the Moscow Synod of 1551, under the pressure from Tsar, approved the cooperation between the state and the Orthodox Church and succeeded in freeing Maxim the Greek. In 1996 the Russian Orthodox Church canonised Maxim the Greek after his relics had been found. The Synod, called the Council of a Hundred Chapters (Stoglav), triggered a revival movement in the Russian Orthodox Church. The most outstanding figure of that movement was archpriest Avvakum, who established his own religious community beyond the official structures of the Orthodox Church, referred to as Old Believers (starovertsy). That time witnessed a dynamic development of the monastic centre on the Solovetsky Islands in the White Sea. Solovetsky saints Savvatii (+1435), Zosima $(+1478)$ and Herman $(+1484)$ launched a magnificent spiritual centre of Russian Orthodoxy.

During the reign of Ivan IV the Terrible, Muscovy entered wars with Sweden and Poland, and began conquering Siberia. The conflict was unavoidable also between the ruler and the clergy. The Metropolitan of Moscow Philip demanded that the Orthodox Church gain autonomy and fell victim to Tsar's fury (1568). Metropolitan Philip, besides metropolitans of Moscow Peter $(+1326)$, Alexy $(+1378)$ and Iona $(+1461)$, now belong to the saints that are paid a special worship. Those metropolitans stood up for the independence of the Orthodox Church from the state power. A similar position was assumed by archbishop of Novgorod St. Gennadiy (+1504) Tsarevich Dmitry, prince of Moscow and Uglich, was also proclaimed saint $(+1591)^{10}$.

In the $16^{\text {th }}$ century in the Muscovite lands the movement of the Fools-for-Christ (yurodivy) emerged. This specific group of prophets, who originated from different social classes, was famed for the great charisma that could influence Tsar's decisions and the attitudes of his court. Theological thinking and iconography were at that time in decline. After Ivan IV's death, during the rule of Boris Godunov, in 1589 Moscow was granted the status of a patriarchate. Metropolitan of Moscow, Job was appointed the first patriarch of Moscow and All Russia.

Muscovy was first named Russia in the late $15^{\text {th }}$ century. The name was popularised during the $16^{\text {th }}$ century and

\footnotetext{
8 J. A. Babinov, Evolucyja gosudarstvienno-tserkownych otnoshennii w Rossijskoj imperii, [In:] Cywilizacja Rosji Imperialnej, pp. 265-266.

9 J. Keller, Prawosławie, Warszawa 1982, pp. 183-184.

10 A. Mironowicz, The Orthodox Church in Czarist Russia, [w:] Russia of the Tsars, Russia of the Bolsheviks, Russia of the New Time, ed. J. Malicki, Warszawa 2012, s. 7-16.
} 
in 1721 it became the official designation of the state. Russia was a multinational country. Besides the Russians, the population included the Belarusians, Ukrainians, Germans, Tatars, Bashkirs and Mordvins. After conquering of Siberia in the $17^{\text {th }}$ century Russian society was extended with the Yakuts, Buryats, Evenks and others.

After Boris Godunov's death Russia had to challenge internal conflicts, in historical terms referred to as the Time of Troubles. During the period of Polish interventions in Russia, known as the Dmitriad wars, the state structure was undermined. The upheavals of peasantry and the Cossacks, Polish invasions and the efforts of the Pope to enforce the ecclesiastical union left Russia ruined and its cities deserted. The Time of Troubles reunited the Orthodox Church and the state. Patriarch Hermogenes, before he was arrested and starved to death in Polish imprisonment (+1612), had called on people to revolt. Shortly afterwards, Hermogenes was proclaimed Hieromartyr of the Russian Orthodox Church. ${ }^{11}$

As foreign troops were expelled from Moscow in 1613, the Tsar's crown was offered to Michael Romanov, the son of patriarch Filaret, who established the Romanov Dynasty. Until 1694 the relations between the state and the Church were exemplarily harmonious. The state structures grew in importance during the reign of Alexy Mikhailovich, when after the war with the Polish-Lithuanian Commonwealth Russia acquired the Left-bank Ukraine with Kiev, together with the Chernihiv, Bratslav and Siversk lands. At that time, there was an increase in religious awareness of the Russians. In 1652 Nikon was appointed patriarch and went on to reform liturgy and some ceremonies, and introduced certain corrections in the Russian Church books. The modifications covered the Orthodox Church orthography and the pronunciation of the word Jesus („Iisus” instead of „Isus”). The patriarch essentially influenced the political life and choices of Tsar Alexy Mikhailovich. Nikon's reform met with the opposition concentrated around the above-mentioned archpriest Avvakum. The Moscow Synod convened in 1666 approved Nikon's reforms and anathematised Avvakum's supporters. Avvakum's supporters, the Old Believers, were to face prosecutions. Avvakum himself, held in imprisonment for several years, was finally sentenced to the stake. In 1667 Nikon was tried by the Eastern patriarchs over his theocratic rule in the Orthodox Church and deprived of the dignity.

Religious life in Russia was overthrown during the reign of Peter I (1682-1725). The Russian Orthodox Church could not form an effective opposition to the political reforms of Peter I who, after the death of patriarch Adrian (1700), obstructed the election of his successor. Finally, Peter the Great abolished the patriarchate and replaced it with the institution of the Holy Synod, whose members were appointed by himself. The Holy Synod was in fact governed by a layman in the rank of a higher prosecutor. The abolition of the patriarchate of Moscow was an

\footnotetext{
11 Sviashchennomuchenik Jermogen, patriarkh moskovski i vsieja Rossii, chudotworets, [In:] Pravoslavnyje sviatyni, Moscow 2003, pp. 77-81.
}

act contrary to the old structures of the Orthodox Church, against the Orthodox canons and the entire Byzantine and Ruthenian-Russian tradition. This decision of Peter I affected the activities of the Russian Church in a profound manner. ${ }^{12}$

After the death of Peter I, Russia was struck by an internal crisis. The state regained power during the reign of Empress Elisabeth (1741-1762) and Empress Catherine II (1763-1796). Russia annexed south-eastern Finland, won two wars with Turkey, succeeded in diminishing the position of Prussia and France, and participated in the partition of the Commonwealth. The territorial gains of Russia extended its population with followers of other Christian and non-Christian denominations. In 1796 the Russians accounted for $48.9 \%$ of the total headcount of 41,175 thousand people. Besides the Russians, the Empire was inhabited by the Ukrainians $(19.8 \%)$, Belarusians $(8.3 \%)$, Poles (6.2\%), Tatars (2.2\%), Finns (2.2\%), Lithuanians (2.0\%), Latvians $(1.7 \%)$, Jews $(1.4 \%)$, Estonians $(1.2 \%)$, Mordvins $(0.8 \%)$, Chuvash $(0.8 \%)$, Germans $(0.6 \%)$, Bashkirs $(0.5 \%)$ and other nationalities $(2.9 \%)$. The national divisions reflected the denominational differences. The followers of Orthodoxy prevailed among the Russians, Armenians, Belarusians and Ukrainians. A part of the Belarusians and Ukrainians adhered to Greek Catholicism and some of the Russians were the Old Believers. The Poles and Lithuanians, together with a share of the Germans and Armenians, were Roman Catholics. Protestantism dominated among the Latvians, partly the Germans, Finns and Estonians. Islam was the religion of Tatars and other peoples in the Asian region of Russia. The Jews followed Judaism. The remainder of nationalities adhered to Buddhism, Lamaism and pagan religions. ${ }^{13}$

In the $18^{\text {th }}$ century subsequent spheres of activity of the Orthodox Church were much suppressed, especially during the reign of Catherine II. The „enlightened empress” in 1764 succeeded in eliminating ca. $75 \%$ of the monasteries, while their property was secularised. Metropolitan of Rostov Arsenius was defrocked and imprisoned for opposing the prosecutions. A deep clash emerged between the rulers of Russia, moved by western ideas, and the clergy and common people, which remained faithful to the old Eastern Christian tradition. That gave a fertile ground for a broad-scale sectarian movement to thrive on.

The $18^{\text {th }}$ century witnessed another revival of religious life in Russia, accompanied by the growing importance of the Orthodox Church in the public sphere. The Russian theological school was stimulated by the more and more popular teachings of bishop of Voronezh St. Tikhon Zadonsky (1724-1783). Inspired by the Gospel and the works

\footnotetext{
12 N. Pablenko, Piotr Pervyj, Moscow 1975, pp. 306-307; W. A. Serczyk, Piotr I Wielki, Wrocław 1990; B. A. Uspieński, W. M. Żywow, Car $i$ Bóg. Semiotyczne aspekty sakralizacji monarchy $w$ Rosji, Warszawa 1992, pp. 86-88; A. Mironowicz, Polityka Piotra I wobec Kościoła prawosławnego w Rosji $i$ w Rzeczypospolitej, [In:] Cywilizacja Rosji Imperialnej, P. Kraszewski, ed., Poznań 2002, pp. 277-294.

13 W. M. Babuzan, Narody Rossii w piervoj połovinie XIX v. Chisliennost $i$ etnicheskij sostav, Moscow 1992, p. 125; P. Eberhardt, Geografia ludności Rosji, Warszawa 2002, pp. 87-88.
} 
of the Holy Fathers of Orthodoxy, his preaching promoted the idea of the common character of human salvation. Owing to his efforts new monastic centres, specialised in contemplation and prayer, were founded in the $19^{\text {th }}$ century. The Russian monasticism was increasingly moved by the institution of Elderhood (starchestvo), the body of monks of eminent piety and wisdom. The revival of monastic life was instigated by the monk St. Paisius Velichkovsky, who lived in the $18^{\text {th }}$ century $(1722-1794)$. He is also claimed to have reinstated intellectual work in monasteries and cultivated the study of the teachings of the Orthodoxy Holy Fathers. The work by St. Paisius Velichkovsky Dobrotolubiye, which is a collection of extracts from the writings of the Greek Orthodoxy Fathers, has been the basic studybook on the infallible principles of Christian life.

The views of the charismatic elderly who had the gift of prophecy (the disciples of St. Paisius Velichkovsky, monks of the Optina hermitage),${ }^{14}$ and especially those of St. Seraphim of Sarov, influenced the Russian elites, including Tsar himself. St. Seraphim (1759-1833) preached the joyful gospel of Christ's resurrection. He would welcome the visitors to his hermitage near Sarov with the phrase: „Let us rejoice, Christ is risen, indeed He is risen!" The Optina hermitage was visited for advice by philosophers and writers, including Nikolay Gogol (1809-1852), Fyodor Dostoevsky (1821-1911), Vladimir Solovyov (1853-1900), Leo Tolstoy (1828-1911) and others. ${ }^{15}$ Their works were satiated with Christian ethics and philosophy. Pavel Florensky and Sergei Bulgakov discovered the universe and God's love of man precisely in Orthodoxy. The elites of St. Petersburg were much under the charm of nun Xenia who came from an aristocratic family but by physical work and prayer attained the gift of healing. ${ }^{16}$

The power of Russia grew under the reign of Alexander I (1800-1824), in particular after the Napoleon army was beaten off Moscow in 1812. The Russian Tsar was the instigator of the Holy Alliance and Russia was nicknamed the Gendarme of Europe. Alexander I maintained a policy of toleration towards other denominations. During the reign of Nikolay I Russia annexed Azerbaijan (1828), Bessarabia (1829) and vast territories in Central Asia with their non-Christian peoples. In order to secure support on the part of the Russian citizens, Tsar promoted the ideology of an Orthodox state based on a symbiosis of „Orthodoxy, absolutism and nationality". The theory of the official folk character contained in the formula "the Orthodox faith, autocracy and nationality" was created by Segej Uwarow in 1833. The concept was later developed by the official historiographer of the Empire, Nikolai Ustrialov in The Russian History published in the years 1837-1841. Experi-

\footnotetext{
14 Optina Pustyń, [In:] Pravoslavnyje sviatyni, Moscow 2003, pp. 302308 .

15 Istochnik sviatogo Serafima, [In:] Pravoslavnyje sviatyni, pp. 8-12; A. Mironowicz, Cerkiew prawosławna $w$ dawnej $i$ we współczesnej Rosji, [w:] Bizancjum - Prawostawie - Romantyzm. Tradycja wschodnia w kulturze XIX wieku, pod red. J. Ławskiego i K. Korotkicha, Białystok 2004, p. $55-74$

16 Chasovnia błazhennoj Ksienii Pietierburgskoj, [In:] Pravoslavnyje sviatyni, pp. 44-48.
}

enced with the November uprising the catholic and Polish influence was forced out of the western provinces of the Empire and its inhabitants were persuaded to unite with the Russia and the Orthodox Church ${ }^{17}$. Contrary to his predecessor, Tsar Nikolay I favoured the integrist tendencies in the Orthodox Church. Creating the awareness of historical ties with Russia and Russian Orthodox Church, especially among the Lithuanians, Belarusians and Ukrainians, constituted an important element of crating bonds amid the inhabitants of the Empire. Kievan Rus, treated as a Russian state, led to the creation of the Russian Empire through the Vladimir-Suzdal Rus and Grand Duchy of Moscow.

In the $19^{\text {th }}$ century the Russian Empire was struck by multiple national upheavals and peasant unrests. In this situation, Tsar Alexander II enfranchised the peasantry (1861) and introduced reforms of the army, judiciary and state administration. Alexander III substantially reduced the depth of those reforms. The Tsar supported the development of capitalist social relationships. New industrial centres were established in the Donetsk region and in Baku. The Orthodox Church opted for the liberation of peasants from the feudal bonds yet was reluctant to any revolutionary and socialist tendencies, so popular among the Russian intelligentsia. The circles of the higher clergy recultivated the ideas of the Church's independence of the state. Metropolitan of Moscow Filaret (+1867) was an ardent supporter of the Church's autonomy. Other bishops, faced with the failure of any efforts to free the Orthodox Church from dependence on the state, chose to live monastic life, as for instance St. Ignatius Branchaninov (1807-1867), St. Ambrosius of the Optina hermitage $(+1891)$ or Theophan the Hermit (1815-1894). The isolation of the Russian clergy was much due to its rooting in families of priests. Another movement among the clergy was represented by St. Ioann of Kronstadt (1829-1909). The priest hailed the participation in everyday liturgy, support to the poor and the need for educating social masses. ${ }^{18}$

In the late $19^{\text {th }}$ century national movements prevailed in the Russian Empire and nationality and religion converged. In 1897 the Russian territories were dominated by Orthodox population (75\%), which inhabited mainly the European part of Russia and the Siberian regions colonised by the Russians. Orthodoxy was rather weak in the peripheral provinces of the Empire. The Congress Kingdom of Poland was dominated by Catholics, Finland, Estonia and Latvia featured most Protestants, while Muslims prevailed in Central Asia. In total, Russia of 1897 had 87.121 million Orthodox believers, 11.468 million Catholics, 2.199 million Old Believers, 1.218 million Armenian Orthodox Church followers, 3.764 million Protestants, 13.906 mil-

\footnotetext{
A. de Lazari, Narodowość oficjalna, [in:] Idee w Rosji. Leksykon rosyjsko-polsko-angielski, pod red. Andrzeja de Lazari, vol. I, Warszawa 1999, p. 280; K. Błachowska, Wiele historii jednego państwa. Obraz dziejów Wielkiego Księstwa Litewskiego do 1596 roku w ujęciu historyków polskich, rosyjskich, ukraińskich, litewskich i białoruskich $w$ XIX wieku, Warszawa 2010, p. 71-72.

18 O. Clément, Kościół prawosławny od roku 1054 do współczesności, [In:] Encyklopedia religii świata, vol. I, Historia, Warszawa 2002, pp. 465-466.
} 
lion Muslims, 5.214 million Jews and 170 thousand Buddhists and Lamaists. ${ }^{19}$

In the early $20^{\text {th }}$ century the Orthodox Church raised the demands of independence and reactivation of patriarchate. In 1904 the decision was taken to convene the Synod. Presynodal commissions began their works with the view to reforming the Orthodox Church and determining its position in the state. Meanwhile, the defeat of Russia in the Russo-Japanese war (1904-1905) and the revolution of 1905-1907 prompted the political reform. Tsar's October Manifesto of 1905 introduced religious toleration, extended the scope of civil freedoms, limited censorship and established a surrogate of the parliament, the State Duma. Tsar Nikolay II was under a strong influence of Rasputin, who claimed to be an elderly. Rasputin's advice had had a negative effect on the rule of the last member of the Romanov Dynasty. A sharp conflict emerged between the Orthodox hierarchs and the court. ${ }^{20}$

The outbreak of World War I and the defeats suffered in the first years of the war made the revolutionary tendencies imminent. Unemployment, an ever-growing influence of social-democrat parties among Russian society and the domestic crisis led to the February Revolution followed shortly by the October Revolution in 1917. The latter overthrew the democratic government and proclaimed the communist dictatorship, which lasted until 1991. In the times of both revolutions the Orthodox Church remained faithful to Tsar. After the subversion of monarchy but before the Bolshevik prosecutions of the Orthodox Church began, the Kremlin Synod managed to restore the canonical elect ability of bishops and reactivate the patriarchate. Archbishop of Vilnius Tikhon was appointed patriarch of Moscow in 1918.

The Orthodox Church was not meant to have a period of peace. The communist regime was fighting the Orthodox church as well as other Churches and religious associations until 1988. The Christians, especially the orthodox ones, were heavily persecuted and tormented.

After a long period of subduing the Orthodox Church by the secular authorities (from the times of Peter I to

\footnotetext{
19 P. Eberhardt, Geografia ludności Rosji, pp. 117-119.

20 J. A. Babinov, Evolucyja gosudarstvienno-tserkownych otnoshennij v Rossiskoj impierii, pp. 270-271.
}

Mikhail Gorbachev's perestroika) an essential change in the policy towards the Russian Orthodox Church did not occur until 1988. From the ceremonial commemoration of the 1000 years of the Kievan Rus, the Orthodox Church regained its subjectivity and freedom. Analysing the situation of Orthodox Church in Russia it is worth noticing that the rapprochement of the Russian Orthodox Church with the state led to the emergence of xenophobic and isolationist tendencies among the orthodox community and created in the country the synonym of the terms "orthodox" and the person "of Russian nationality. Before 1917 the policy of the Russian Orthodox Church hierarchy and the state was aiming at the transformation of the Orthodox faith into national religion. Such situation was beneficial for both sides, but not for long: the common act of the state and the Church against sectarian, infidel movements and even against the tendencies incompatible with tradition, culture and Russian identity. ${ }^{21}$.

In the long run, bringing the Church under Tsar's authority made it act as a tool in the imperial policy of the state of Russia. The Orthodox church was slowly losing its independence and evangelizing was heavily marked with the state policy. The Russian Orthodox Church used to be an integral part of the state structure of Russia in the tsarist times. Evangelization of Russian lands was carried out by means of the state apparatus. The Russian Orthodox Church, as well as Byzantine Church was closely connected with the state, with all possible consequences resulting from that fact. The rulers in Russia always strove to consolidate the state and society by means of the Church. Christianity was strengthening the functioning social structure and gave the possibilities of cultural and intellectual development for all Russian citizens. However, subduing the Church to the state have always resulted in losing its independence. The apostolic principles were at first the origins of the alliance between the state and the Church; however, the symbiosis of the Russian Orthodox Church and the state in the Russian Empire is based on the domination of the tsar's power over the church hierarchy and not on the mutual benefits ${ }^{22}$.

\footnotetext{
21 M. Patyna, Rosyjska Cerkiew Prawosławna, [in:] http://www.rosjapl. republika.pl/cerkiew/kosciol.html

22 J. A. Babinov, Evolucyja gosudarstvienno-tserkovnykh otnoshennij v Rossiskoj impierii, pp. 272-276.
}

\section{Bibliography}

Babinov J. A., Evoljucija gosudarstvenno-cerkovnych otnošenij $v$ Rossijskoj Imperii, [w:] Cywilizacja Rosji Imperialnej, red. P. Kraszewski, Poznań 2002.

Bazylow L., Historia Rosji, t. 1-2, Warszawa 1983.

Błachowska K., Wiele historii jednego państwa: Obraz dziejów Wielkiego Księstwa Litewskiego do 1596 roku w ujęciu historyków polskich, rosyjskich, ukraińskich, litewskich i biatoruskich w XIX wieku, Warszawa 2010.
Brajčevs'kyj M. J., Utverždenije christijanstva na Rusi, Kyjiv 1988.

Časobnia blažennoj Ksenii Peterburgskoj, [w:] Pravoslavnyje sviatyje, Moskva 2003.

Cechanskaja K. V., Rossija: tendencii religioznosti $v$ XX veke, „Istoričeskij Wiestnik”, 2000, № 5.

Čistovič I., Očerki istorii Zapadno-Russkoj Cerkvi, Č. 1, Sankt-Peterburg 1882. 
Clément O., Kościót prawosławny od roku 1054 do współczesno$s ́ c i$, [w:] Encyklopedia religii świata, cz. 1: Historia, Warszawa 2002.

Cypin V., Istorija Russkoj Cerkvi (1917-1997), Moskva 1997.

Dubin B., Massovoje pravoslavije v Rossii (devjanostyje gody), [w:] Strona internetowa portalu Index, http:www.index.org. ru.

Eberhardt P., Geografia ludności Rosji, Warszawa 2002.

Fedotov G. P., Sviatyje drevniej Rusi (X-XVII st.), New York 1959.

Firsov S. L., Pravoslavnaja Cerkov'i gosudarstvo v posledneje desiatiletie suščestvovanija samoderžavija v Rossii, Sankt-Peterburg 1996.

Floria B., Otnošenija gosudarstva i cerkvi u vostočnych i zapadnych slavian, Moskva 1992.

Gajek J. S., U początków świętości Rusi Kijowskiej, [w:] Chrystus zwyciężyt: Wokół chrztu Rusi Kijowskiej, red. J. S. Gajek, W. Hryniewicz, Warszawa 1989.

Golubinskij E., Istorija kanonizacii svjatych v Russkoj Cerkvi, Moskva 1903.

Golubinskij E., Istorija Russkoj Cerkvi, T. 1, Moskva 1903.

Hruševs'kyj M., Istorija Ukrajiny-Rusy, T. 3, Kyjiv 1905.

Istočnik sviatogo Serafima, [w:] Pravoslavnyje sviatyje, Moskva 2003.

Kabuzan V. M., Narody Rossii v pervoj polovine XIXv. Čiselnost' i etničeskij sostav, Moskva 1992.

Kaševarov A. N., Cerkov'i vlast': Russkaja Pravoslavnaja Cerkov'v pervyje gody Sovetskoj vlasti, Sankt-Peterburg 1999.

Keller J., Prawostawie, Warszawa 1982.

Kempfi A., O XI-wiecznym metropolicie kijowskim Hilarionie i Hilarionowym , Stowie o Zakonie i Łasce”, „Rocznik Teologiczny", 1987, R. XXIX, nr 2.

Kirilova N. A., Vlast'i cerkov'v 1922-1925 gg., Moskva 1997.

Kologrivov I., Očerki istorii russkoj svjatosti, Bruxelles 1961.

Kowalska H., Kultura staroruska XI-XVI w.: Tradycja i zmiana, Kraków 1998.

Kroniki staroruskie, wybór, wstęp i przypisy F. Sielicki, Warszawa 1987.

Kucharzewski L., Od białego caratu do czerwonego, t. 1-2, Warszawa 1990.

L' Église orthodoxe en Europe orientale au XX siècle, sous la direction de Ch. Chaillot, Paris 2009.

Lazari A. de, Narodowość oficjalna, [w:] Idee w Rosji: Leksykon rosyjsko-polsko-angielski, red. A. de Lazari, t. 1, Warszawa 1999.

Łowmiański H., Początki Polski, t. 1, Warszawa 1963.

Makarij (M. Bulgakov), Istorija Russkoj Cerkvi, kg. 2, Moskva 1995.
Mel'nikov A. A., Put' nepečalen: Istoričeskije svidetel'stva o sviatosti Beloj Rusi, Minsk 1992.

Mironowicz A., Organizacja Kościoła prawosławnego na ziemiach ruskich $w$ XI- XIII wieku, [w:] Ecclesia. Cultura. Potestas: Studia z dziejów kultury i społeczeństwa. Księga ofiarowana Siostrze Profesor Urszuli Borkowskiej OSU, red. P. Kras i inni, Kraków 2007.

Mironowicz A., Polityka Piotra I wobec Kościola prawosławnego w Rosji i w Rzeczypospolitej, [w:] Cywilizacja Rosji Imperialnej, red. P. Kraszewski, Poznań 2002.

Mironowicz A., Święci w Cerkwi prawosławnej na Białorusi, [w:] Wilno i kresy pótnocno-wschodnie, t. 1: Historia i ludzkie losy, red. E. Feliksiak, A. Mironowicz, Białystok 1996.

Ochmański J., Dzieje Rosji do roku 1861, Warszawa 1986

Optina Pustyn', [w:] Pravoslavnyje sviatyni, Moskva 2003.

Pateryk Kijowsko-Pieczerski czyli opowieści o świętych ojcach w pieczerach kijowskich położonych, oprac. L. Nodzyńska, Wrocław 1993.

Pavlenko N., Petr Pervyj, Moskva 1975.

Pipes R., Rosja carów, Warszawa 1990.

Podskalsky G., Christentum und theologische Literatur in der Kiever Rus'(988-1237), München 1982.

Poppe A., Olga, [w:] Słownik starożytności słowiańskich, t. 3, Wrocław 1975.

Poppe A., Państwo i Kościól na Rusi w XI wieku, Warszawa 1968.

Poppe A., Ruś i Bizancjum w latach 986-989, „Kwartalnik Historyczny", 1978, nr 1.

Poppe A., The Rise of Christian Russia, London 1982.

Rapov O. M., Russkaja Cerkov'v IX-pervoj treti XII v., Moskva 1988.

Roberti J. C., Struvé N., Popielovski D., Historie de l'Église russe, Paris 1989.

Serczyk A. W., Prehistoria imperium czyli imperialne oblicze absolutyzmu rosyjskiego, [w:] Cywilizacja Rosji Imperialnej, red. P. Kraszewski, Poznań 2002.

Serczyk W. A., Piotr I Wielki, Wrocław 1990.

Serczyk W. A., Poczet władców Rosji, Londyn 1992.

Ševčenko I., Byzantine Roots of Ukrainian Christianity, Harvard 1984.

Sviaščennomučenik Ermogen, patriarch moskovskij i vseja Rusi, čudotvorec, [w:] Pravoslavnyje sviatyje, Moskva 2003.

Swastek J., Chrzest Rusi, [w:] Teologia i kultura duchowa Starej Rusi, red. W. Hryniewicz, J. S. Gajek, Lublin 1993.

Uspieński B. A., Żywow W. M., Car i Bóg: Semiotyczne aspekty sakralizacji monarchy w Rosji, Warszawa 1992.

Wójcik Z., Dzieje Rosji, 1533-1801, Warszawa 1981.

Žitija sviatych, sobr. monachiniej Taisijej, kg. 1-2, New York 1983. 
ISSN 1508-7719

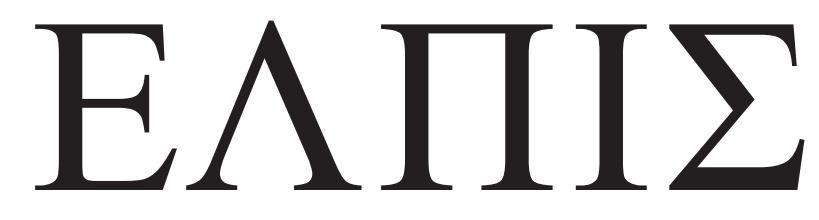

CZASOPISMO TEOLOGICZNE KATEDRY TEOLOGII PRAWOSŁAWNEJ UNIWERSYTETU W BIAŁYMSTOKU

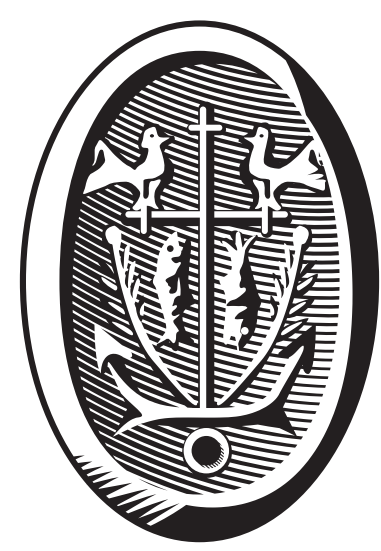

ADRES REDAKCJI

15-097 Białystok, ul. M. Skłodowskiej-Curie 14 tel. 85 745-77-80, e-mail: redakcja@elpis.edu.pl www.elpis.uwb.edu.pl 